\title{
Isolation and Mycelial Growth of Mushrooms on Different Yam-based Culture Media
}

\author{
Nootjaree Tudses \\ Department of Plant Science, Faculty of Agricultural Technology and Industrial Technology, Phetchabun Rajabhat University, Thailand.
}

\begin{tabular}{|c|c|}
\hline ARTICLE INFO & ABSTRACT \\
\hline $\begin{array}{l}\text { Article history: } \\
\text { Received on: } 19 / 04 / 2016 \\
\text { Revised on: } 06 / 06 / 2016 \\
\text { Accepted on: } 02 / 08 / 2016 \\
\text { Available online: } 23 / 10 / 2016\end{array}$ & $\begin{array}{l}\text { This study reports the potential application of yams as an efficient substrate for isolating mushrooms from the } \\
\text { fruiting body. It seems that the utilization of yams as the medium for edible mushroom cultivation, i.e. a } \\
\text { substitute for PDA, may increase the economic value of yams. Yams (Dioscorea sp.) belong to the starch-rich } \\
\text { and energy-rich tubers, together with cassava, sweet potato, and potato. There is little utilization of yams in } \\
\text { Thailand because yams grow wild and uncultivated and thus sufficient quantities of yams are available for home }\end{array}$ \\
\hline $\begin{array}{l}\text { Key words: } \\
\text { Culture media, Dioscorea } \\
\text { sp., Edible mushroom, Yam. }\end{array}$ & $\begin{array}{l}\text { consumption and in local markets. In this study, an experiment was performed to assess the suitability of yam- } \\
\text { based culture media as a potentially high value material for edible mushroom isolation and mycelial growth as a } \\
\text { substitute for potato dextrose agar (PDA). Yam-based culture media were prepared from three species (D. alata } \\
\text { L., D. esculenta and } D \text {. pentaphylla) in varying concentrations }(0,5,10,15,20,25 \text {, and } 30 \% \text { (w/v)). PDA was } \\
\text { used as the standard medium. Three edible mushrooms, i.e. Pleurotus sajor-caju (Fr.) Sing., Lentinula edodes, } \\
\text { and Volvariella volvacea were investigated. Mycelial growth of the mushrooms was measured the average } \\
\text { mycelium colony diameter on the different media. The results of mycelial growth of the mushrooms show that } \\
\text { yam-based culture media can be used as alternative culture media for cultivation. }\end{array}$ \\
\hline
\end{tabular}

\section{INTRODUCTION}

Yams (Dioscorea sp.), together with cassava, sweet potato and potato, belong to the starch-rich and thus energy-rich tubers. Yams are more restricted to limited areas and well-known to villagers in the north and northeastern part of Thailand as a rice supplement. A chemical extract from some species has been found to have a potential use as an insecticide, and yams are also used as a healthy food and source of herbal medicinal ingredients [1]. Normally, it is used boiled or steamed and sometimes cooked with sugar-coconut milk. D. alata L., D. esculenta, and D. hispida are the most important yam species; several other species have been identified, but few have been collected. Scientists hope to collect more species as plant facilities improve. The utilization of yams for the formulation of laboratory media has been done for the cultivation of Pleurotus

* Corresponding Author Nootjaree Tudses, Department of Plant Science, Faculty of Agricultural Technology and Industrial Technology, Phetchabun Rajabhat University, Thailand. Email: nootjaree_tudses @ yahoo.com tuber-regium (Fr.) Sing. and P. sajor caju [2, 3], as well as the production of mycelial biomass, exopolysaccharides and mycelium protein [4], the isolation of tuber-rot fungi [5] and cultivated fungi $[6,7,8]$, and as an efficient substrate for mushroom cultivation [9]. One of the most important general purpose agar media is Potato Dextrose Agar (PDA). The feasibility of developing alternative media to different culture media, particularly PDA, has been studied by different researchers. There is low utilization of yams in Thailand because yams grow wild and uncultivated and thus sufficient quantities of yams are available for home consumption and in local markets. This study aimed to evaluate the potential application of yams as a source of efficient substrate-modified agar media for the mycelium growth of mushrooms.

The process of culturing mushrooms has three main steps: isolating the mushroom from the fruiting body, preparing primary and secondary spawn, and culturing the mushroom from spawn to harvest fruiting bodies [10]. The aim of this study was to evaluate the effects and to find the optimal concentrations of yams that allow for mycelial growth of three mushroom species, including Lentinula edodes, Pleurotus sajor-caju (Fr.) Sing., and Volvariella volvacea, with the goal of promoting mycelial growth. 


\section{MATERIAL AND METHODS}

This investigation was carried out research laboratory of Department of Plant Science, Faculty of Agricultural Technology and Industrial Technology, Phetchabun Rajabhat University, Thailand during October to November, 2015. The details of materials and methods are described as below;

\subsection{Material preparation}

Three different yam species were as the substrate, i.e. D. alata L., D. esculenta, and D. pentaphylla, and were tested for their ability to support mycelial growth. The edible mushrooms included L. edodes, P. sajor-caju (Fr.) Sing., and V. volvacea, obtained from a farm located in Muang, Phetchabun, Thailand.

\subsection{Yam-based culture media preparation}

The different culture media, i.e. DADA (D. alata L. Dextrose Agar), DEDA (D. esculenta Dextrose Agar), and DPDA (D. pentaphylla Dextrose Agar) were compared with PDA (Potato Dextrose Agar) for mycelial growth. The yam-based culture media were used in different concentrations at $0-30 \%(w / v)$ of each yam species. The skin was peeled from $500 \mathrm{~g}$ of yams and cut into small pieces, then $300 \mathrm{~g}$ of each yam and $200 \mathrm{~g}$ of potato was carefully weighed. They were then boiled in $500 \mathrm{ml}$ of water for 15 min. The yam extract was prepared by filtering through muslin cloth and then used for medium preparation. The extract was made up to $1,000 \mathrm{ml}$ using distilled water. The composition of the medium included $20 \mathrm{~g}$ of dextrose and $15 \mathrm{~g}$ of agar for solid media. An Erlenmeyer flask containing $150 \mathrm{ml}$ of medium was cotton plugged and autoclaved at $121^{\circ} \mathrm{C}$ for $15 \mathrm{~min}$. After cooling to about $45^{\circ} \mathrm{C}$, it was then dispensed into Petri dishes in duplicate.

\subsection{Mushroom culture}

Fresh cultures of L. edodes, P. sajor-caju (Fr.) Sing., and $V$. volvacea were cut with sterilized blades, then a small piece of the mushroom tissue was removed and placed on PDA medium and incubated at $25^{\circ} \mathrm{C}$ for 10 days. Several sub-cultures were made until pure cultures were obtained. Mycelium discs $(5 \mathrm{~mm}$ in diameter) from seven-day-old mushroom cultures were inoculated in each Petri dish (placed in the center of the medium) and incubated at $25^{\circ} \mathrm{C}$ for seven days in darkness. The diameter of the mycelium expansion was measured for seven days and colony morphology was recorded.

\subsection{Measurement of mycelial growth}

The vegetative growth of the mycelium of the mushroom on the different media was assessed by measuring the diameter of mycelium in the Petri dish prior to inoculation.

\subsection{Mother spawn preparation}

Sweet sorghum seeds as the spawning material to support extensive mycelial growth were washed in clean water three times to remove dust and other particles. The grains were then soaked in water for $24 \mathrm{~h}$ for maximum absorption of water. Soaked grains were again washed in water drained and put into spawn bottles. About 2/3 of each spawn bottle were filled with grains after which they were autoclaved at $121^{\circ} \mathrm{C}$ for $15 \mathrm{~min}$. The grains in the bottles were then inoculated with five mycelium discs $(5 \mathrm{~mm}$ in diameter) per bottle under aseptic conditions. They were incubated at $30^{\circ} \mathrm{C}$ for 14 days. Inoculated bottles were gently shaken for 5 and 10 days.

\section{RESULTS AND DISCUSSION}

The present study points to the importance of an underutilized tuber crop such as D. alata L., D. esculenta, and D. pentaphylla (Fig. 1) on mycelial growth for commercial applications. There were three culture media which cultured mushrooms successfully in the laboratory environment. All the tested materials showed positive results for mycelial growth, which are provided in Table 1. The mycelial extension of $L$. edodes, P. sajor-caju (Fr.) Sing., and V. volvacea was compared on different culture media. The colony characteristics of all three mushroom species grown on yam-based culture media were assessed for 7 days.

The highest mycelial growth of $V$. volvacea was $9.00 \pm 0.00 \mathrm{~cm}$ on DPDA-30; for P. sajor-caju (Fr.) Sing. This was $5.47 \pm 0.42 \mathrm{~cm}$ and for $L$. edodes this was $3.73 \pm 0.06 \mathrm{~cm}$ on DADA20 and DADA-25, respectively $(\mathrm{p}<0.05)$ (Table 1$)$. To determine the optimal concentration of yams for mycelial growth, the concentration of $5-30 \%(\mathrm{w} / \mathrm{v})$ DADA and DPDA gave the greatest mycelium colony diameter $(2.50 \pm 0.00$ to $9.00 \pm 0.00 \mathrm{~cm}$.). The highest mycelium colony diameter of $L$. edodes $(3.73 \pm 0.06 \mathrm{~cm}$.) cultured on DADA was achieved at $20-25 \%$ (w/v). However, the highest concentration of DEDA medium was unable to increase the mycelium colony diameter. It is thought that the type of yam and or a high concentration of yam-based culture medium may inhibit mycelial growth.

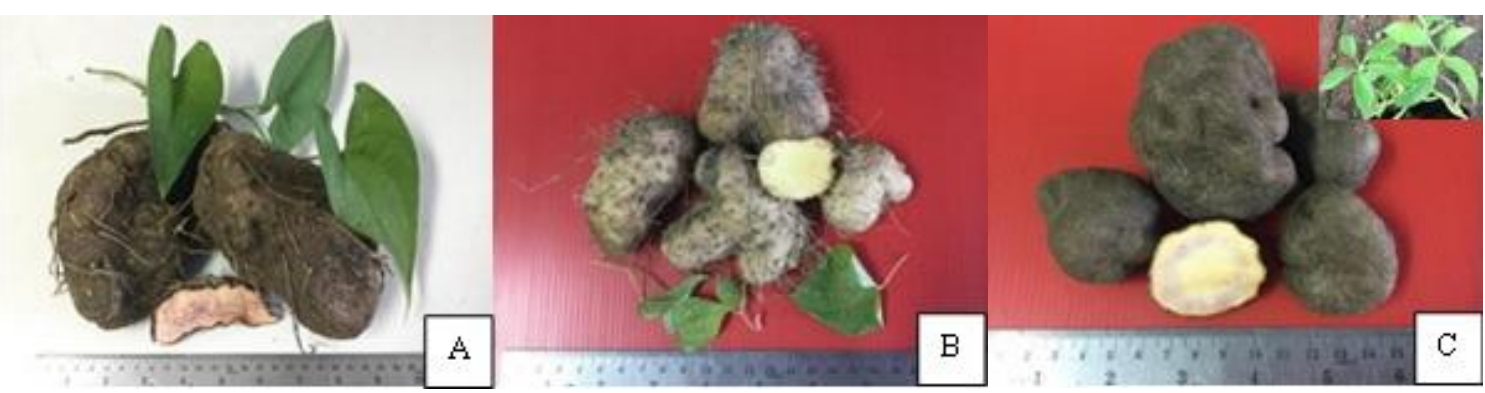

Fig. 1: Showing different tubers and leaves of three Dioscroea sp. A) D. alata L. B) D. esculenta and C) D. pentaphylla 
Table 1: Effect of different culture media on the mycelial growth of mushrooms cultured for 7 days

\begin{tabular}{|c|c|c|c|c|}
\hline \multirow[t]{2}{*}{ Culture media } & \multirow{2}{*}{$\begin{array}{c}\text { Concentration } \\
(\% \text { w/v })\end{array}$} & \multicolumn{3}{|c|}{ Mycelium colony diameter $(\mathrm{cm})$} \\
\hline & & L.edodes & P. sajor-caju (Fr.) Sing. & V. volvacea \\
\hline \multirow[t]{7}{*}{ DADA } & 0 & $1.57 \pm 0.15^{\mathrm{fg}}$ & $2.43 \pm 0.40^{\mathrm{de}}$ & $6.14 \pm 0.25^{\mathrm{d}}$ \\
\hline & 5 & $2.60 \pm 0.17^{\mathrm{de}}$ & $3.30 \pm 0.26^{\mathrm{cd}}$ & $4.93 \pm 0.21^{\mathrm{e}}$ \\
\hline & 10 & $3.10 \pm 0.30^{\mathrm{bc}}$ & $4.43 \pm 0.38^{\mathrm{b}}$ & $6.23 \pm 0.25^{\mathrm{d}}$ \\
\hline & 15 & $3.27 \pm 0.06^{\mathrm{b}}$ & $4.10 \pm 0.56^{\mathrm{bc}}$ & $3.57 \pm 0.32^{\text {fg }}$ \\
\hline & 20 & $3.37 \pm 0.58^{\mathrm{a}}$ & $4.67 \pm 0.35^{\mathrm{ab}}$ & $4.70 \pm 1.04^{\mathrm{e}}$ \\
\hline & 25 & $3.73 \pm 0.06^{\mathrm{a}}$ & $4.40 \pm 0.89^{\mathrm{b}}$ & $4.10 \pm 0.53^{\mathrm{ef}}$ \\
\hline & 30 & $3.70 \pm 0.50^{\mathrm{a}}$ & $4.10 \pm 0.53^{\mathrm{bc}}$ & $3.67 \pm 1.44^{\mathrm{fg}}$ \\
\hline \multirow[t]{7}{*}{ DEDA } & 0 & $1.67 \pm 0.06^{\mathrm{fg}}$ & $2.03 \pm 0.25^{\text {ef }}$ & $0.50 \pm 0.00^{j}$ \\
\hline & 5 & $1.20 \pm 0.17^{\mathrm{h}}$ & $0.50 \pm 0.00^{\mathrm{h}}$ & $4.20 \pm 0.53^{\mathrm{ef}}$ \\
\hline & 10 & $1.23 \pm 0.06^{\mathrm{gh}}$ & $2.73 \pm 0.40^{\mathrm{de}}$ & $3.57 \pm 0.15^{\mathrm{fg}}$ \\
\hline & 15 & $0.83 \pm 0.06^{\mathrm{jk}}$ & $3.13 \pm 0.64^{\mathrm{d}}$ & $2.70 \pm 0.17^{\mathrm{h}}$ \\
\hline & 20 & $0.63 \pm 0.06^{\mathrm{k}}$ & $2.67 \pm 0.42^{\mathrm{de}}$ & $2.43 \pm 0.32^{\mathrm{hi}}$ \\
\hline & 25 & $0.70 \pm 0.17^{\mathrm{k}}$ & $1.97 \pm 0.15^{\mathrm{ef}}$ & $2.97 \pm 0.06^{\mathrm{gh}}$ \\
\hline & 30 & $0.50 \pm 0.00^{\mathrm{k}}$ & $1.63 \pm 0.32^{\mathrm{fg}}$ & $1.83 \pm 0.15^{\mathrm{i}}$ \\
\hline \multirow[t]{7}{*}{ DPDA } & 0 & $1.33 \pm 0.25^{\mathrm{ij}}$ & $0.50 \pm 0.00^{\mathrm{gh}}$ & $0.50 \pm 0.00^{\mathrm{j}}$ \\
\hline & 5 & $2.50 \pm 0.00^{\mathrm{e}}$ & $4.37 \pm 0.49^{\mathrm{b}}$ & $8.23 \pm 0.21^{\mathrm{ab}}$ \\
\hline & 10 & $2.77 \pm 0.06^{\text {cde }}$ & $4.33 \pm 0.21^{b}$ & $7.63 \pm 0.21^{\mathrm{bc}}$ \\
\hline & 15 & $2.93 \pm 0.23^{\mathrm{bcd}}$ & $3.30 \pm 0.17^{\mathrm{cd}}$ & $7.37 \pm 0.40^{\mathrm{c}}$ \\
\hline & 20 & $2.63 \pm 0.06^{\mathrm{de}}$ & $4.27 \pm 0.83^{b}$ & $7.20 \pm 0.69^{c}$ \\
\hline & 25 & $2.87 \pm 0.29^{\text {cde }}$ & $5.47 \pm 0.42^{\mathrm{a}}$ & $7.63 \pm 0.32^{\mathrm{bc}}$ \\
\hline & 30 & $2.93 \pm 0.12^{\mathrm{bcd}}$ & $4.17 \pm 0.76^{\mathrm{bc}}$ & $9.00 \pm 0.00^{\mathrm{a}}$ \\
\hline PDA & 20 & $3.27 \pm 0.56^{\mathrm{b}}$ & $3.10 \pm 0.10^{\mathrm{d}}$ & $7.20 \pm 0.26^{\mathrm{c}}$ \\
\hline
\end{tabular}

DADA: D. alata L. Dextrose Agar; DEDA: D. esculenta Dextrose Agar;

DPDA: D. pentaphylla Dextrose Agar; PDA: Potato Dextrose Agar.

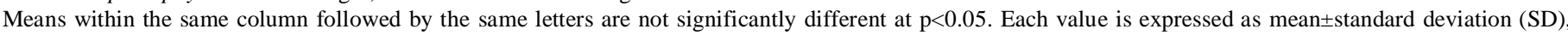
$\mathrm{n}=3$.

The observed mycelium colony diameter of mushrooms on different media was significantly different at $\mathrm{p}<0.05$. The results of the present research show that the mycelia of $L$. edodes and P. sajor-caju (Fr.) Sing. formed on DADA and DPDA faster than on DEDA medium. However, the difference in the average mycelial growth between PDA and DPDA was not significant ( $p>0.05)$. The mycelia that grew on DADA, DEDA and DPDA were thinner than on PDA (Fig. 2). It seems that the colony characteristics of the mycelium depend on the medium composition, the efficacy of biocompounds, the type of yam species and the concentrations of the substrate $[4,11,12]$.

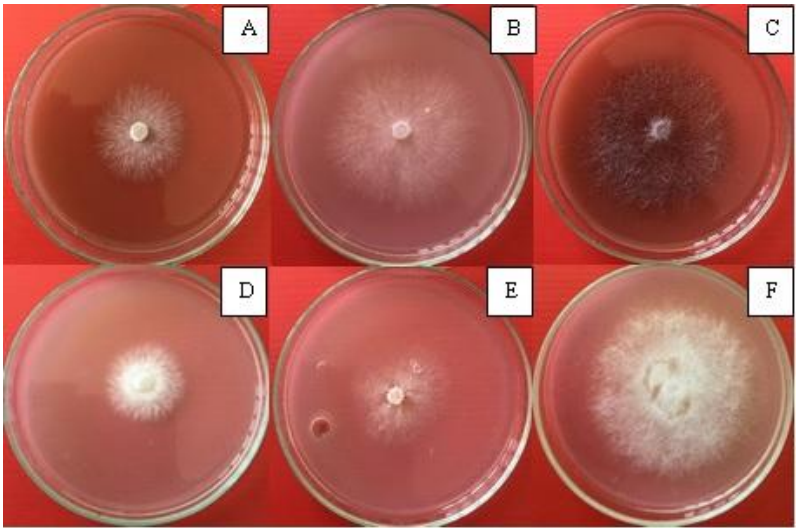

Fig 2: Morphology of mycelia growth of $V$. volvacea (A), P. sajor-caju (Fr.) Sing. (B), and $L$. edodes (C) cultured on yam-based culture media and $V$. volvacea (D), P. sajor-caju (Fr.) Sing. (E), and L. edodes (F) cultured on PDA for 7 days $($ bar $=0.5 \mathrm{~cm})$

In this study, it was evident that some media supported the growth of some strains of mushroom better, which means that each needs to be studied individually. Fai et al. [13] applied a commercially available culture media of yam bean as a tuber substrate to produce chitin and chitosan by Mucor circinelloides. This is in agreement with the findings of Vikraman et al. [8] who reported that tuber crops, especially Dioscorea, are bestowed with an immense starch content, which can be used as a food source for fungal culture. Hoa and Wang [14] reported the use of alternative culture media for growing oyster mushrooms (P. ostreatus and P. cystidiosus). Mother spawn production as a pure culture of mycelium growing on a solid substrate such as cereal grain has a fundamental role in agricultural productivity. In this study, $V$. volvacea and $P$. sajor-caju (Fr.) Sing. were fully colonized by vigorously growing mycelia on sweet sorghum as the spawn after 14 days of incubation (Fig. 3); L. edodes was the exception. Stanley and Awi-Waadu [15] reported a trend for the duration of incubation on different types of grain type on mycelial fresh extension.

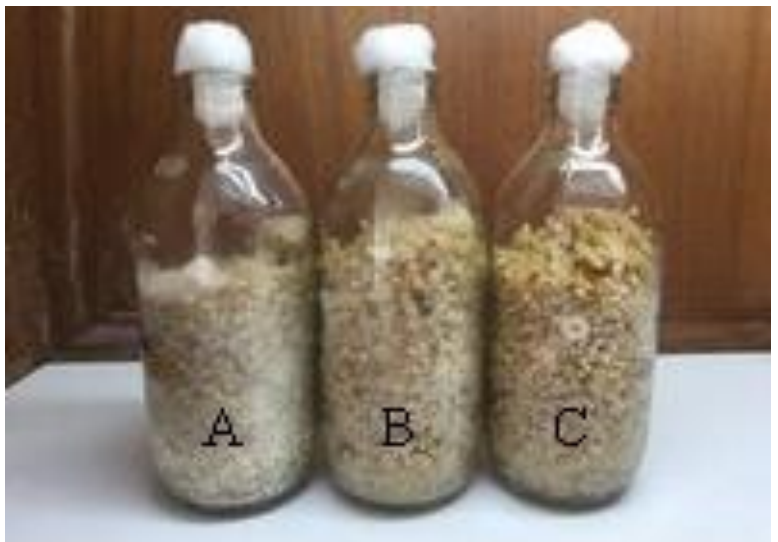

Fig 3: Spawn grains of $V$. volvacea (A), P. sajor-caju (Fr.) Sing. (B), and $L$. edodes $(\mathrm{C})$ cultured on sweet sorghum grains. 


\section{CONCLUSIONS}

This study reports the potential application of yams as an efficient substrate for isolating mushrooms from the fruiting body. Yam-based culture media of DPDA was found suitable for mycelium growth for P. sajor-caju (Fr.) Sing and V. volvacea. It seems that the utilization of yams as the medium for edible mushroom cultivation, i.e. a substitute for PDA, may increase the economic value of yams. Further research is still needed to assess the application of temperature and nutritional conditions on the mycelial growth of mushrooms and to determine the effects of substrates for spawn preparation on the mycelial growth of three mushrooms.

\section{ACKNOWLEDGMENTS}

We are grateful to the Department of Plant Science, Faculty of Agricultural Technology and Industrial Technology, Phetchabun Rajabhat University for providing the facilities to carry out the experiment and the Office of the Higher Education Commission (R2559A041).

Conflict of Interests: There are no conflicts of interest.

\section{REFERENCES}

1. Liu SY, Wang JU, Shyu YT, Song LM. Studies of yams (Dioscorea spp.) in Taiwan. Journal of Chinese Medicine. 1995;6(2):111-126.

2. Okhuoya, JA,Okogbo FO. Cultivation of Pleurotus tuber-regium (Fr) Sing on various wastes. Proceedings of the Oklahoma Academy of Science archive. 1991;17:1-3.

3. Stanley HO, Odu NN, Onwuka JU. The effect of honey on the Mycelial Growth of Pleurotus sajor caju (Oyster mushroom). International Research Journal of Environment Science. 2013;2(12):13-18.

4. Mshandete AM, Mgonia JR. Submerged liquid fermentation of some Tanzanian Basidiomycetes for the production of mycelial biomass, exopolysaccharides and mycelium protein using waste peel media. ARPN Journal of Agricultural and Biological Science. 2009;4(6):1-13.

5. Nwawuisi JU, Odoh IN, Anele UM. Developing culture media from yam species (Dioscorea rotundata): technique for isolation of tuber-rot fungi of yam. Agricultural Journal. 2012;7(4):260-263.

6. Amadi OC, Moneke AN. Use of starch containing tubers for the formation of culture media for fungal cultivation. African Journal of Microbiology Research. 2012;6(21): 4527-4532.
7. Janet I, Isaac O, Abigil O, Mary N, Ijeoma N. Utilization of food crop wastes for the formulation of laboratory media used for cultivating soil fungi. Global Journal of Microbiology Research. 2014;2(1):112-116.

8. Vikraman N, Joseph J, Ragi PR, Anil KN. Media standardization for the mass multiplication of a bio-control agent, Trichoderma asperellum. International Journal of Current Research. 2014; 6(11): 9979-9983.

9. Dzomeku M, Narhmensah DL, Obodai M, Prempeh J, Takli RK, Komlaga G, Dziedzoave NA, Sonnenberg A. Vegetative growth of different strains of Pleurotus and Lentinula species on cassava (Manihot esculenta) and yam (Dioscorea rotundata) wastes in Ghana. In Proceedings of the $8^{\text {th }}$ International Conference on Mushroom Biology and Mushroom Products (ICMBMP8). 2014:280-285.

10. Dung LB. Mushrooms in Tay Ngyen. Ha Noi: Science and Technology;2003.

11. Kim SW, Hwang HJ, Park JP, Cho YJ, Song CH, Yun JW. Mycelial growth and exo-biopolymer production by submerged culture of various edible mushrooms under different media. Letters in Applied Microbiology. 2002;34:56-61.

12. Lee $\mathrm{S}$, Bae H, Kim N, Hwang S. Optimization of growth conditions of Lentinus edodes mycelium on corn processing waste using response surface analysis. Journal Bioscience and Bioengineering. 2008;105(2):161-163.

13. Fai AEC, Stamford TCM, Stamford-Arnaud TM, Santa-Cruz PDA, Freitas da Silva M C, Campos-Takaki GM, Stamford TLM. Physicochemical characteristics and functional properties of chitin and chitisan producted by Mycor circinelloides using yam bean as substrate. Molecules. 2011;16:7143-7154.

14. Hoa HT, Wang C-L. The Effects of temperature and nutritional conditions on mycelium growth of two oyster mushrooms (Pleurotus ostreatus and Pleurotus cystidiosus). Mycrobiology. 2015;43(1):14-23.

15. Stanley HO, Awi-Waadu GD. Effect of substrates of spawn production on mycelial growth of oyster mushroom species. Research Journal of Applied Sciences. 2010; 5(3): 161-164.

\section{How to cite this article:}

Nootjaree Tudses. Isolation and Mycelial Growth of Mushrooms on Different Yam-based Culture Media. J App Biol Biotech, 2016; 4 (05): 033-036. doi: 10.7324/JABB.2016.40505 